\title{
Comparative Study of the Effects of Two Organic Manures on Soil Physico-Chemical Properties, and Yield of Potato (Solanum tuberosum L.)
}

\author{
Muyang Rosaline Fosah ${ }^{1,2, *}$, Mbouobda Hermann Desire ${ }^{1,3}$, Fotso ${ }^{1,3}$, Foasung-Zah Elvis ${ }^{1}$, \\ Taffouo Victor Desire ${ }^{2}$ \\ ${ }^{1}$ Department of Biology, Higher Teachers Training College (HTTC), the University of Bamenda, Bamenda, Cameroon \\ ${ }^{2}$ Department of Botany, Faculty of Science, University of Douala, Douala, Cameroon \\ ${ }^{3}$ Laboratory of Plant Biology, Department of Biological Sciences, Ecole Normale Supérieure (ENS), University of Yaoundé 1, Yaounde, \\ Cameroon
}

\section{Email address:}

wanfosah3@yahoo.com (M. R. Fosah)

\section{To cite this article:}

Muyang Rosaline Fosah, Mbouobda Hermann Desire, Fotso, Foasung-Zah Elvis, Taffouo Victor Desire. Comparative Study of the Effects of Two Organic Manures on Soil Physico-Chemical Properties, and Yield of Potato (Solanum tuberosum L.). Plant. Vol. 4, No. 1, 2016 , pp. 1-7. doi: 10.11648/j.plant.20160401.11

\begin{abstract}
A field experiment was conducted in Bambili, North West Region of Cameroon to evaluate the morphological and agronomic parameters of potato grown in soil treated with two organic manures as well as soil physico-chemical properties. A randomized complete block design (RCBD) with three treatments (EM manure, IMO manure and control), and four replications was conducted. Results showed significant differences $(\mathrm{P} \leq 0.05)$ in the height of plants and leaf area index throughout the period of experiment in plants treated with both manures. IMO manure produced taller plants $(65.150 \pm 17.850$ $\mathrm{cm})$ compared to EM manure $(57.642 \pm 12.146 \mathrm{~cm})$ and the control plants $(19.070 \pm 4.215 \mathrm{~cm})$. The highest leaf area index was recorded by plants treated with IMO manure followed by those treated with EM manure, and then the control. The fresh weight of tubers produced by IMO manured plants $(241.64 \pm 32.94 \mathrm{~g})$ was higher than those of EM manured plants $(227.62 \pm$ $44.58 \mathrm{~g})$, and control $(125.66 \pm 31.63 \mathrm{~g})$. Both IMO and EM manures had significant positive effects on soil physico-chemical properties, morphological parameters, and yields. However, IMO manure had better effects. Soil physico-chemical properties revealed a decrease in electrical conductivity, total phosphorus, calcium content and magnesium content. IMO treated soil recorded the higher rate of decrease, followed by EM treated soil and control soil, total organic carbon increased while total nitrogen content did not change during experiment for manure soils.
\end{abstract}

Keywords: Solanum tuberosum, Manures, Yield, Soil, Properties

\section{Introduction}

Potato (Solanum tuberosum) is one of the most valuable and widely consumed tuber crops in Cameroon. The main production areas are localized in the highland zones of the West, Northwest, Southwest, Adamawa, Far north and Littoral regions [1]. In these Western Highlands of Cameroon, approximately over 200,000 smallholder farmers are involved in the production of potato. Their production makes up more than $80 \%$ of the national production, estimated at 142,000 tons per year cultivated on 45,000 ha [2]. In addition, between 1986 and 2009, these western highland farmers raised potato yields from 2.5 to 5 tons per hectare [3]. However, these yields per unit area and total production are still very low, looking at the existing potential in the area. Low yields are due to a number of restraining factors including high cost of inputs, low soil fertility and unsustainable farming practices [4].

The physico-chemical properties and microbial component of soil determines its fertility. The most important minerals needed for the growth of potato plants are $\mathrm{N}, \mathrm{P}, \mathrm{K}$, and $\mathrm{Mg}$ [5]. Intensive cropping system heavily drains the available nutrients in the soil, thus reducing its productivity. Hence soil nutrients need to be replenished. It is estimated that more than $50 \%$ increase in yield is due to chemical fertilizers. However, they have also polluted the environment and caused slow deterioration of soil health. The chemical 
residues in food produced also cause injury to human beings and cattle population [6]. Furthermore, the use of mineral fertilizers over a long period of time results in reduction in soil base saturation and increased acidity [7], while the application of organic amendments improves soil physicochemical properties and crop yield over time [8].

Organic farming encourages the use of environmentally friendly organic manures such as Effective Microorganism (EM) manure and Indigenous Microorganism manure (IMO) which are made up of effective and beneficial microorganisms [9]. These microorganisms have been shown to be effective in improving soil health and quality, and raising the growth, yield and quality of crops [10]. IMO is made up of a local group of microbes which have the propensity to regenerate very fast because of their adaptations to the local conditions of the environment. However, the use of mixed cultures of beneficial microorganisms as soil inoculants to enhance growth, health, yield and quality of crops is still questionable by researchers since the claim lacks conclusive scientific proof [11]. EM is a fermented mixed culture of naturally occurring species of microorganisms living together in acidic medium. Plants grown with EM manure were only as good or better, and quality of plant products was superior compared to those of conventional farming $[12,13,14]$. In addition, the effect of EM on crop yield was usually not evident or even negative particularly in the first test crop $[15,16,17,18]$. The purpose of this experiment was therefore to evaluate some soil physico-chemical properties, plant morphological parameters, and agronomic parameters of potato grown in soil treated with two organic manures, EM manure and IMO manure.

\section{Materials and Methods}

\subsection{Location}

The experiment was carried out at a research farm in a quarter in Bambili, called "Mekele" along the road to Ndop during the period of April to August 2013. It is located at Latitude $05^{\circ} 59^{\prime} 18.5^{\prime \prime}$ north and longitude $010^{\circ} 17^{\prime} 15.4$ " east, and 1578 meters above sea level. Bambili is situated in Tubah Sub-Division, Mezam Division of the North West Region of Cameroon. Bambili has a false guinnean monsoon wind and a mixture of Cameroonian and continental guinnean climate. There is great variation in the monthly temperatures with the maximum in February $\left(27^{\circ} \mathrm{C}\right)$ and the minimum in December $\left(17^{\circ} \mathrm{C}\right)[19]$.

\subsection{Preparation of Manures, Application and Planting}

EM manure was prepared according to the method of [20], whereas IMO manure was prepared according to the method of [21], using local farming field material. $38 \mathrm{~g}$ of each treatment was applied 1 week before planting per hole. Potato seed tubers with 3 to 6 eyes were planted at $30 \mathrm{~cm}$ apart. Weeds were controlled manually and by mulching done 4 and 8 weeks after planting (WAP).

\subsection{Land Preparation and Field Management}

A piece of land was cleared using a cutlass and raked. Thereafter, the land was ploughed and beds $(5 \mathrm{~m}$ long and 1 $\mathrm{m}$ wide) were made using a hoe. The experimental design was the randomized complete block design (RCBD) with three treatments (EM manure, IMO manure and control) and 4 replications. The crops were sprayed against late blight disease (Phytophthora infestans) with a fungicide (Manizan) every week from the fourth to the twelfth WAP.

\subsection{Evaluation of Morphological Parameters}

Plant height and leaf area index were measured using a tape every week from the $4^{\text {th }}$ to the $10^{\text {th }}$ WAP. Plant height was taken from the base to the terminal bud, and leaf area index was calculated according to [22].

\subsection{Harvesting}

Potato tubers were harvested 12 WAP after planting, when the leaves and stems had turned yellowish brown. The weight of tubers per treatment was recorded.

\subsection{Soil Sampling and Analysis}

Soil sampling was done with a sampling auger at a depth of $0-15 \mathrm{~cm}$ at five points on each bed before application of manures, and one and 9 weeks after application. The soils were air dried, ground, and sieved using a $2 \mathrm{~mm}$ sieve and then analyzed for total phosphorus (TP), total organic carbon (TOC), total nitrogen content (TNC), calcium $\left(\mathrm{Ca}^{2+}\right)$ and magnesium $\left(\mathrm{Mg}^{2+}\right)$ contents using standard procedures of [23].

\subsection{Data Analysis}

The data obtained were expressed as means \pm SD and were statistically analysed using the SPSS statistical software Version 17.0 (SPSS Inc., Chicago). The significant difference between mean values was determined using analysis of variance (ANOVA). Student Newman-Keuls (SNK) test was used to compare means at 0.05 level of significance.

Table 1. Variation of height of potato plants $(\mathrm{cm})$ under different treatments with time.

\begin{tabular}{llll}
\hline Duration & Parameters & & \\
\hline & EM & IMO & Control \\
\hline 4 & $20.485 \pm 5.88 \mathrm{a}$ & $21.600 \pm 4.489 \mathrm{a}$ & $19.070 \pm 4.215 \mathrm{a}$ \\
5 & $29.345 \pm 6.574 \mathrm{~b}$ & $29.225 \pm 5.388 \mathrm{~b}$ & $25.940 \pm 8.029 \mathrm{ab}$ \\
6 & $36.510 \pm 9.118 \mathrm{c}$ & $37.265 \pm 7.937 \mathrm{c}$ & $32.068 \pm 11.444 \mathrm{bc}$ \\
7 & $42.480 \pm 8.813 \mathrm{c}$ & $46.675 \pm 9.061 \mathrm{~d}$ & $37.761 \pm 12.712 \mathrm{~cd}$ \\
8 & $53.126 \pm 11.253 \mathrm{~d}$ & $61.385 \pm 13.752 \mathrm{e}$ & $51.212 \pm 20.925 \mathrm{e}$ \\
9 & $57.642 \pm 12.146 \mathrm{~d}$ & $65.150 \pm 17.850 \mathrm{e}$ & $52.382 \pm 17.716 \mathrm{e}$ \\
10 & $54.563 \pm 18.123 \mathrm{~d}$ & $60.295 \pm 12.227 \mathrm{e}$ & $50.535 \pm 15.849 \mathrm{e}$ \\
P value & 32.479 & 48.258 & 17.305 \\
Sign & 0.000 & 0.000 & 0.000 \\
\hline
\end{tabular}

Means with same letter in the same column are not significantly different $\mathrm{P} \leq$ 0.05 (SNK Test). 


\section{Results}

\subsection{Variation of the Height of Potato Plants}

Results showed a gradual and significant $(\mathrm{P} \leq 0.05)$ increase in height of plants for all treatments up to week 9 but decreased slightly at week 10 . At week 9, IMO manure recorded the longest plant heights $(65.15 \pm 17.85 \mathrm{~cm})$ followed by those treated with EM manure $(57.64 \pm 12.14$ $\mathrm{cm})$, and then control plants $(52.38 \pm 17.71 \mathrm{~cm})$ (Table 1).

\subsection{Variation of Leaf Area Index of Potato Plants}

The leaf area index increased in all treatments till the $7^{\text {th }}$ WAP for EM manure plants and till $8^{\text {th }}$ WAP for IMO manure plants and Control plants with recorded values of $152.217 \pm$ $40.88 \mathrm{~cm}^{2} ; 183.21 \pm 43.05 \mathrm{~cm}^{2}$ and $135.379 \pm 48.158 \mathrm{~cm}^{2}$ as highest leaf area index respectively. Significant differences $(P \leq 0.05)$ were noted within plants of each treatment; control plants recorded the shortest leaf area index (Table 2).

Table 2. Variation of leaf area index ( $\mathrm{cm} 2)$ of potato plants under different treatments with time.

\begin{tabular}{llll}
\hline Duration & Parameters & & \\
\hline & EM & IMO & Control \\
\hline 4 & $119.322 \pm 42.488 \mathrm{a}$ & $105.348 \pm 36.564$ & $91.655 \pm 30.612 \mathrm{a}$ \\
5 & $123.005 \pm 38.064 \mathrm{a}$ & $157.191 \pm 59.362 \mathrm{bc}$ & $107.366 \pm 42.871 \mathrm{ab}$ \\
6 & $133.681 \pm 38.446 \mathrm{ab}$ & $180.236 \pm 49.315 \mathrm{c}$ & $117.856 \pm 55.890 \mathrm{~b}$ \\
7 & $152.217 \pm 40.881 \mathrm{~b}$ & $177.564 \pm 50.637 \mathrm{c}$ & $128.094 \pm 48.020 \mathrm{~b}$ \\
8 & $143.357 \pm 39.746 \mathrm{ab}$ & $183.216 \pm 43.081 \mathrm{c}$ & $135.379 \pm 48.158 \mathrm{~b}$ \\
9 & $136.214 \pm 40.838 \mathrm{ab}$ & $154.201 \pm 41.713 \mathrm{bc}$ & $119.036 \pm 28.351 \mathrm{~b}$ \\
10 & $133.768 \pm 44.654 \mathrm{ab}$ & $137.427 \pm 48.706 \mathrm{~b}$ & $116.955 \pm 40.113 \mathrm{~b}$ \\
P value & 1.523 & 6.940 & 3.062 \\
Sign & 0.000 & 0.000 & 0.000 \\
\hline
\end{tabular}

Means with same letter in the same column are not significantly different $\mathrm{P} \leq$ 0.05 (SNK Test).

\subsection{Evaluation of Productivity}

Plants treated with IMO manure produced potato tubers with the heaviest weight $(241.64 \pm 32.94 \mathrm{~g})$, followed by EM manure $(227.62 \pm 44.58 \mathrm{~g})$, and the control produced tubers with the least weight $(125.66 \pm 31.63 \mathrm{~g})$. Statistical analysis revealed significant differences $(\mathrm{P} \leq 0.05)$ in terms of average weight of tubers for all the treatments (Fig. 1).

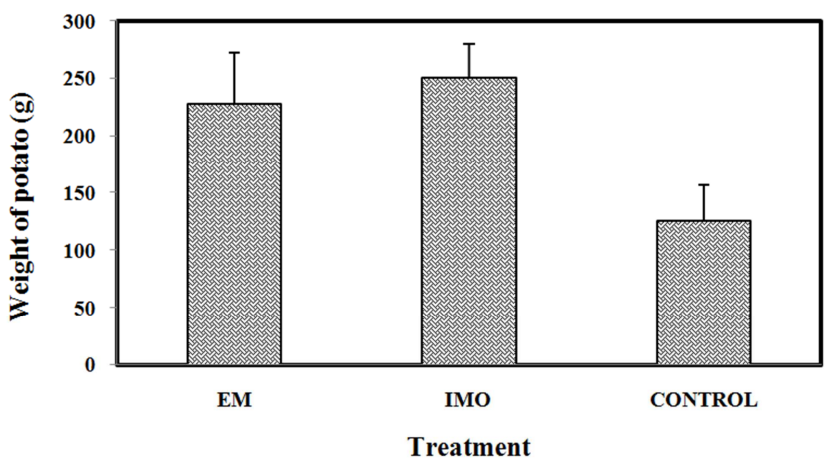

Figure 1. Average weight of potato tubers produced (g) per treatment.

\subsection{Soil Physico-Chemical Properties}

The highest $\mathrm{pH}$ was observed in the control soil (7.3) nine weeks after application of manures while the lowest $\mathrm{pH}$ was recorded in IMO-treated soil (6.12) one week after application (Table 3). IMO manure treated soil recorded the highest electrical conductivity $\left(332 \mathrm{mS} . \mathrm{cm}^{-1}\right)$ one week after application which decreased drastically at nine weeks after application of manure at a rate of $-94.27 \%$ followed by EM manured soil $(-80,62 \%)$. No variation of TNC was observed in both soils treated with EM manure and IMO manure while in the control soil, this TNC decreased between week 1 and week 9 (-16.67). TOC was highest in the soils treated with IMO manure (71100.00 mg. $\mathrm{kg}^{-1}$ ) compare to initial soil (31733.33 mg. $\left.\mathrm{kg}^{-1}\right)$; control soil recorded the higher variation rate (42.35). TP content was also highest in the IMO treated soil $\left(1600.00 \mathrm{mg} \cdot \mathrm{kg}^{-1}\right)$ and lowest in still the same soil $\left(466.67 \mathrm{mg} \cdot \mathrm{kg}^{-1}\right)$ with a rate of decrease of $-70.83 \%$. The highest $\mathrm{Ca}^{2+}$ content was observed in both the EM treated manure soil and the control soil (335.26 mg. $\mathrm{kg}^{-1}$ and 406.40 mg. $\mathrm{kg}^{-1}$ ) while lowest was observed in the IMO treated manure soil $\left(193.32 \mathrm{mg} \cdot \mathrm{kg}^{-1}\right)$ nine weeks after application of manures. The highest $\left(360.66 \mathrm{mg} \cdot \mathrm{kg}^{-1}\right)$ and lowest $(85.83$ mg. $\left.\mathrm{kg}^{-1}\right) \mathrm{Mg}^{2+}$ contents were observed in the IMO treated manure soil one and nine weeks after application of manures respectively but this content decreased at the rate of $-75.52 \%$; $-47.95 \%$ in IMO treated manure soil, EM treated manure soil respectively while no variation was observed in control soil (Table 3).

Table 3. Soil physico-chemical properties of tests and control soils.

\begin{tabular}{|c|c|c|c|c|c|c|c|c|c|c|}
\hline \multirow{3}{*}{$\begin{array}{l}\text { Soil physico- } \\
\text { chemical } \\
\text { properties }\end{array}$} & \multicolumn{10}{|c|}{ TREATMENTS } \\
\hline & \multicolumn{3}{|c|}{ EM manure } & \multicolumn{3}{|c|}{ IMO manure } & \multicolumn{3}{|c|}{ CONTROL } & \multirow{2}{*}{$\begin{array}{l}\text { INITIAL } \\
\text { O WEEK }\end{array}$} \\
\hline & Week 1 & Week 9 & $\% \mathrm{~V}$ & Week 1 & Week 9 & $\% \mathrm{~V}$ & Week 1 & Week 9 & $\% \mathrm{~V}$ & \\
\hline EC & 157.9 & 30.6 & -80.62 & 332 & 19.01 & -94.27 & 45 & 23.5 & -47.78 & 24.1 \\
\hline TNC (mg.kg $\left.{ }^{-1}\right)$ & 2008.03 & 2008.03 & 0 & 1004.02 & 1004.02 & 0 & 1204.82 & 1004.02 & -16.67 & 1003.02 \\
\hline TOC (mg.kg $\left.{ }^{-1}\right)$ & 49733.33 & 50566.67 & 1.67 & 71100.00 & 74833.33 & 5.25 & 41166.67 & 58600.00 & 42.35 & 31733.33 \\
\hline $\mathrm{Ca}^{2+}\left(\mathrm{mg} \cdot \mathrm{kg}^{-1}\right)$ & 406.24 & 335.26 & -17.50 & 335.26 & 193.32 & -42.34 & 335.06 & 406.40 & 21.22 & 332.22 \\
\hline $\mathrm{Mg}^{2+}\left(\mathrm{mg} \cdot \mathrm{kg}^{-1}\right)$ & 251.61 & 130.95 & -47.95 & 350.66 & 85.83 & -75.52 & 113.62 & 113.62 & 0.00 & 116.60 \\
\hline
\end{tabular}

$\% \mathrm{~V}$ : Percentage of variation. 


\subsection{Correlation Between Morphological, Agronomic, and Soil Physico-Chemical Parameters}

Analysis of correlation $(\mathrm{P}<0.01)$ between the different parameters studied in the plots treated with EM manure revealed a positive and significant correlation between plant height and leaf area index $\left(\mathrm{r}=0.265^{* *}\right)$ as well as a negative and significant correlation with fresh weight $(\mathrm{r}=$ $0.529 *)$. TOC correlated negatively and significantly with $\mathrm{TP}, \mathrm{Ca}^{2+}$ and $\mathrm{Mg}^{2+}\left(\mathrm{r}=-1.000^{* *}\right)$ while TP positively and significantly correlated with $\mathrm{Ca}^{2+}$ and $\mathrm{Mg}^{2+}$ contents. There was also a positive and significant correlation between $\mathrm{Ca}^{2+}$ and $\mathrm{Mg}^{2+}\left(\mathrm{r}=1.000^{* *}\right)$.

In the plots treated with IMO manure analysis of correlation $(\mathrm{p}<0.01)$ revealed a positive and significant correlation between plant height and LAI $\left(\mathrm{r}=0.300^{* *}\right)$ and with $\mathrm{pH}$ of the soil. TNC also correlated positively and significantly with $\mathrm{Mg}^{2+}\left(\mathrm{r}=1.000^{* *}\right)$, while there was a negative and significant correlation between $\mathrm{pH}$ and TP $(\mathrm{r}=-1.000 * *)$ (Table 4).

In control plots, positive and significant correlation was noticed between plant height and LAI $\left(\mathrm{r}=0.287^{* *}\right)$, while a negative and significant correlation between plant height FW of tubers was also recorded $\left(\mathrm{r}=-0.567^{* *}\right)$. Positive and significant correlation was noticed between TNC and TP in one hand and between $\mathrm{pH}$ and $\mathrm{Ca}^{2+}\left(\mathrm{r}=1.000^{* *}\right)$ in another hand. Negative and significant correlation was recorded between $\mathrm{EC}$ and $\mathrm{Mg}^{2+}$ (Table 4).

Table 4. Correlation between morphological, agronomic and soil parameters.

\begin{tabular}{|c|c|c|c|c|c|c|c|c|c|c|}
\hline EM & Plant H & LAI & F W & TNC & TOC & TP & $\mathrm{Ca}^{2+}$ & $\mathbf{M g}^{2+}$ & pH & EC \\
\hline Plant H & 1.000 & & & & & & & & & \\
\hline LAI & $0.265 * *$ & 1.000 & & & & & & & & \\
\hline FW & $-0.529 *$ & 0.100 & 1.000 & & & & & & & \\
\hline $\mathrm{TNC}$ & -0.800 & 0.800 & 0.800 & 1.000 & & & & & & \\
\hline TOC & 0.200 & 0.000 & 0.200 & 0.000 & 1.000 & & & & & \\
\hline TP & 0.100 & 0.200 & 0.300 & 0.100 & $-1.000 * *$ & 1.000 & & & & \\
\hline $\mathrm{Ca}^{2+}$ & 0.000 & 0.200 & 0.000 & 0.150 & $-1.000 * *$ & $1.000^{* *}$ & 1.000 & & & \\
\hline $\mathrm{Mg}^{2+}$ & 0.000 & 0.000 & 0.100 & 0.200 & $-1.000 * *$ & $1.000 * *$ & $1.000 * *$ & 1.000 & & \\
\hline $\mathrm{pH}$ & -0.400 & 0.400 & 0.400 & 0.200 & 0.894 & -0.894 & -0.894 & -0.894 & 1.000 & \\
\hline $\mathrm{EC}$ & 0.800 & -0.800 & -0.800 & -0.400 & -0.447 & 0.447 & 0.447 & 0.447 & -0.800 & 1.000 \\
\hline IMO & Plant $\mathbf{H}$ & LAI & F W & TNC & TOC & TP & $\mathrm{Ca}^{2+}$ & $\mathrm{Mg}^{2+}$ & pH & EC \\
\hline Plant H & 1.000 & & & & & & & & & \\
\hline LAI & $0.300 * *$ & 1.000 & & & & & & & & \\
\hline F W & -0.289 & -0.396 & 1.000 & & & & & & & \\
\hline $\mathrm{TNC}$ & -0.800 & -0.400 & 0.800 & 1.000 & & & & & & \\
\hline TOC & 0.949 & 0.632 & -0.632 & -0.949 & 1.000 & & & & & \\
\hline TP & $-1.000 * *$ & -0.800 & 0.400 & 0.800 & -0.949 & 1.000 & & & & \\
\hline $\mathrm{Ca}^{2+}$ & -0.600 & 0.000 & 0.400 & 0.800 & -0.738 & 0.600 & 1.000 & & & \\
\hline $\mathrm{Mg}^{2+}$ & -0.800 & -0.400 & 0.800 & $1.000 * *$ & -0.949 & 0.800 & 0.800 & 1.000 & & \\
\hline $\mathrm{pH}$ & $1.000 * *$ & 0.800 & -0.400 & -0.800 & 0.949 & $-1.000 * *$ & -0.600 & -0.800 & 1.000 & \\
\hline EC & -0.400 & -0.200 & -0.600 & 0.000 & -0.211 & 0.400 & 0.400 & 0.000 & -0.400 & 1.000 \\
\hline Control & Plant H & LAI & F W & TNC & TOC & TP & $\mathrm{Ca}^{2+}$ & $\mathrm{Mg}^{2+}$ & pH & EC \\
\hline Plant H & 1.000 & & & & & & & & & \\
\hline LAI & $0.287 * *$ & 1.000 & & & & & & & & \\
\hline FW & $-0.567 *$ & 0.046 & 1.000 & & & & & & & \\
\hline $\mathrm{TN}$ & -0.200 & -0.400 & 0.400 & 1.000 & & & & & & \\
\hline TOC & -0.400 & 0.000 & -0.200 & -0.800 & 1.000 & & & & & \\
\hline TP & -0.200 & -0.400 & 0.400 & $1.000^{* *}$ & -0.800 & 1.000 & & & & \\
\hline $\mathrm{Ca}^{2+}$ & 0.400 & 0.800 & 0.200 & -0.800 & 0.600 & -0.800 & 1.000 & & & \\
\hline $\mathrm{Mg}^{2+}$ & 0.400 & 0.200 & -0.800 & -0.800 & 0.400 & -0.800 & 0.400 & 1.000 & & \\
\hline $\mathrm{pH}$ & 0.400 & 0.800 & 0.200 & -0.800 & 0.600 & -0.800 & $1.000 * *$ & 0.400 & 1.000 & \\
\hline $\mathrm{EC}$ & -0.400 & -0.200 & 0.800 & 0.800 & -0.400 & 0.800 & -0.400 & $-1.000 * *$ & -0.400 & 1.000 \\
\hline
\end{tabular}

** Corr. is significant at .01 level; * Corr. is significant at .05 level.

PH: Plant height; LAI: Leaf area index; NS: Number of stems; FW: Fresh weight. TOC: Total organic carbon; TNC: Total nitrogen content; TP: Total phosphorus.

EC: Electrical conductivity; $\mathrm{pH}$ : logarithm of $\mathrm{H}+$ concentration.

\section{Discussion}

The purpose of this experiment was to evaluate soil physicochemical properties, morphological parameters, and agronomic parameters of potato grown in soil treated with two types of organic manures (EM and IMO). Results showed that plots treated with EM and IMO manures produced taller plants and larger leave area index than the control. In fact nutrient availability notably nitrogen, phosphorus, magnesium, calcium and organic carbon, and soil electrical conductivity were higher in these treated plots as revealed by soil analysis. However, IMO manure produced taller plants and larger leaves than EM manure. This could be because beneficial microorganisms in IMO cause increased rates of decomposition of soil organic matter and associated increases 
in nutrient availability, improved plant nutrient status, a decrease in the prevalence of pathogenic microorganisms and an increase in levels of natural inducible plant defences [21]. Maximum height, increased leaf growth and chlorophyll contents were obtained in IMOs-treated plants compared to chemical fertilizers-treated and control plants by [24] while working on okra, cowpea realized that. Also, [25] found out that beneficial microorganisms in IMO manure significantly suppressed the activity of fungal pathogens in crops of mildly susceptible Rhododendron cultivars thereby enhancing growth.

The yield was greater in the treated soils than the control soil with IMO manure having a greater and more significant yield than EM manure. This could be because EM and IMO manures are organic manures and having a significant role in maintaining and improving the chemical, physical, and biological properties of soils and in sustaining crop yield [26]. IMO manure produced plants with a higher mean leaf area index which perhaps led to a higher synthesis rate of starch stored in the tubers. Beneficial microorganisms in IMO were indigenous to the soil and environmental conditions of the farm and could more easily adapt, unlike those in EM manure which were only imported from abroad [27]. According to [28], earthworms and mycorrhizae could be contributing to increases in soil tilt in IMO plots.

Soil analysis one week after manure application revealed a decrease in $\mathrm{pH}$ in manured soils and an increase in the control soil. This could be due to a higher rate of decomposition of organic matter in the test soils by the microbes in the manures leading to increased soil acidity. Soil $\mathrm{pH}$ affects the ability of plant roots to absorb nutrients and when the level is adjusted out of the tolerance, it can affect negatively plant nutrition, plant growth and susceptibility to pests. The discharge of cane sugar residues from cane sugar industry for example decreased the soil $\mathrm{pH}$ [29]. Increase in $\mathrm{pH}$ noticed with all the treatments nine weeks after application could be due to depletion of organic matter with time.

The higher EC in the test soils could be attributed to their greater water-holding capacity due to the added manures, which was more evident in IMO manure soil than EM manure soil [30]. Increased water-holding capacity may be due to accumulation of organic residues [06]. The result agrees with the reports of $[6,31,32]$, who had increased electrical conductivity. Nine weeks after manure application, the decrease in EC in all the soils could be due to decreased water-holding capacity as a result of reduced organic residues [06]. In fact, soil EC is affected by water management of soil, which in turn affects crop yields, crop suitability, plant nutrient availability and activity of soil microorganisms.

The higher $\mathrm{Mg}^{2+}$, TP, and TOC in the test soils compared to the control soil could be as a result of a higher rate of mineralization in the test soils. Soils treated with EM and IMO manures showed higher values in organic carbon, total $\mathrm{N}, \mathrm{K}$, and $\mathrm{Mg}$ as compared to urea treatment [33]. These nutrients were higher in the IMO treated soil compared to the EM manure soil probably due to a higher rate of mineralization since the microorganisms in IMO manure were indigenous to the environment and could easily adapt.
$\mathrm{Mg}$ is a structural component of the photosynthetic pigment, chlorophyll; and phosphorus increases water use efficiency, encourages vigorous root and shoot growth, and promotes early maturity [34]. Hence the higher $\mathrm{Mg}$ and $\mathrm{TP}$ contents in IMO manure-treated soil perhaps explains why the plants had longer stems, higher leaf area index and consequently greater yield compared to EM manure and control. Similar reports were made by $[32,24]$ that in the IMOs treated soil, the discharge of effluents from cotton ginning mill enhanced the soil total phosphorus contents and increased plant chlorophyll content than control soil. EM manure soil showed the highest TNC throughout the study period perhaps was due to the fact that the manure had the highest number of nitrogen fixing bacteria. Application of EM had a positive effect on the net mineralization of nitrogen [35]. The higher calcium content one week after application in EM manured soil compared to IMO manured soil could be attributed to the higher $\mathrm{pH}$ in the EM manured soil.

A progressive increase in soil TOC over time was observed in all the treatments. These results could be due to increased decomposition which increases the level of soil humus that favors root growth to better explore soil phosphorus and calcium. [36].

The soil Mg content of EM manure was the highest throughout the study period. EM manure enhances mineralization of organic matter and improves soil quality [37], and $\mathrm{Mg}$ functions in sugar synthesis, starch translocation, nutrient uptake control and as a carrier of phosphorus in plants.

\section{Conclusion}

Both EM and IMO manure had a positive effect on the growth parameters (plant height and leaf area index) as well as yields of potato in Bambili when compared with the control plants. However plants treated with IMO manure had better results in terms of growth and yield when compared to those treated with EM manure. Soil inoculation with EM and IMO manures improved soil physico-chemical properties. Therefore EM and IMO manures can be used for effective growth and yield of potato, and also to improve soil physicochemical properties.

\section{References}

[1] Fontem, D. A., Demo, P., and Njualem, D. K. (2004). Status of potato production, marketing and utilisation in Cameroon, ISTRC-AB conference in Mombasa, Kenya, 31 October-6 November 2004.

[2] Demo, P., Akaroda, M. O., Njualem, D. K., Koi, J. T., Deffo, V., and Nana, S. F. (1998). Effects of different seed tuber sizes on sprouting, emergence, haulm development, and yield of potato (Solanum tuberosum L.) in the Western Highlands of Cameroon: Tuber yield and tuber size, in: M. O. Akoroda, J. M. Ngeve (Eds.), Root Crops in the 21 Century, Proceedings of the Seventh Triennial Symposium of the International Society for Tropical Root Crops-Africa Branch, Cotonou, Benin, Oct. 11-17, 1998. 
[3] Fontem, D. A., and Schippers, R. R. (2004). Solanum scabrum mill, in: G. J. H. Grubben, O. A. Denton (Eds.), Plant Resources of Tropical Africa 2, Vegetables, PROTA Foundation, Wageningen, Netherlands/Backhungo Publishers, Leiden. 493-498.

[4] Muthoni, J., and Nyamongo, D. O. (2009). A review of constraints to ware Irish potato production in Kenya. Journal of Horticulture and Forestry. 1 (7): 5167-5176.

[5] Van der Zaag, W. D. E. (1992). Potatoes and their cultivation in the Netherlands. Netherlands Potato Consultative Institute and The ministry of Agriculture and Fisheries. pp. 1-47.

[6] Sumathi, T., Janardhan, A., Srilakhmi, A., Sai Gopal D. V. R., and Narasimha, G. (2012). Impact of indigenous microorganisms on soil microbial and enzyme activities. Arch. Appl. Sci. Res., 4 (2): 1065-1073.

[7] Hills, A., Miller E. and Miller, A. (2000). Management of soil acidity in agricultural land [Western Australia]: Farm note 80/2000 Agriculture Western Australia, Lake Grace.

[8] Yaduvanshi, N. P. S. (2003). Substitution of inorganic fertilizers by organic manures and the effect on soil fertility in rice-wheat rotation on reclaimed sodic soil in India. J. Agric. Sci., 140: 161-168.

[9] Shao, X. H., D. Y. Liu, L. Zhu and H. Wang (2001). Prospect of EM treatment techniques of organic waste water for agricultural irrigation. Advances in Science and Technology of Water Resources 21(1), 16-19.

[10] Li, W. J., Sun, Q. L., Umemura, H., Cai, H., Niu, L. A., and Ni, Y. Z. (1999). Application of EM technology for intensive organic recycling, soil quality, crop yield and quality, and environmental protection. In: $\mathrm{Xu}, \mathrm{H}$. L (Editor), Nature Farming and Sustainable Environment, 137-148.

[11] Szymanski, N., Patterson, R. N. (2003). Effective microorganisms (EM) and waste water systems in future directions for on-site systems. Best management practice. pp. 259-262.

[12] Javaid, A. (2009) Growth, nodulation and yield of black gram [Vigna mungo (L.) Hepper] as influenced by biofertilizers and soil amendments. A. J. Biotechnol. 8: 5711-5717.

[13] Xu, H. L. (2000). Effects of a microbial inoculant and organic fertilizers on the growth, photosynthesis and yield of sweet corn. J Crop Prod 3: 183-214.

[14] Yamada, K., Xu, H. L. (2000). Properties and applications of an organic fertilizer inoculated with effective microorganisms. J Crop Prod 3: 255-268.

[15] Daiss, N., Lobo, M. G., Socorro, A. R., Bruckner, U., Heller, J., Gonzalez, M. (2008). The effect of three organic preharvest treatments on Swiss chard (Beta vulgaris L. var. cycla L.) quality. Eur. Food Res. Technol. 226: 345-353.

[16] Mayer, J., Scheid, S. Oberholzer, H. R. (2008). How effective are "Effective Microorganisms"? Results from an organic farming field experiment. In Cultivating the Future Based on Science. Proceedings of the Second Scientific Conference of the International Society for Organic Agriculture Research (ISOFAR), 168-171. ISOFAR; Bonn, Germany.

[17] Javaid, A. and Shah, M. B. M. (2010). Growth and yield response of wheat to EM (Effective microorganisms) and parthenium green manure. A. J. Biotechnol. 9: 3378-3381.
[18] Javaid, A., Bajwa, R., Anjum, T. (2008). Effect of heat sterilization and EM (effective microorganisms) application of wheat (Triticum aestivum L.) grown in organic matter amended soils. Cereal Res. Com. 36: 489-499.

[19] Hatier-Paris (1977). République Unie du Cameroun, régions naturelles. Cartographie GT-Ga belli \& $\mathrm{C}^{\mathrm{ie}}$, Paris (sermap).

[20] Higa, T. (1991). Effective microorganisms: A biotechnology for mankind. Sunmark Publishing Inc, Tokyo. pp. 8-14.

[21] Helen. J., Leopold, G., Gerry, G. (2006). A handbook of preparations, techniques and organic amendments inspired by nature farming and adapted to locally available materials and needs in the Western Visayas region of the Philippines. Natural farming manual. pp. 1-37.

[22] Jose, S., Gillespie, A. R., and Biele (2000). Defining completion vector in a temperate alley cropping system in the midstream U. S. A. 2 competition for water. Agroforestry system. 48: 40-49.

[23] Gregorich, E. G., and Carter, M. R. (2007). Soil Sampling and Methods of Analysis. Canadian Society of Soil Science.

[24] Soma, M. S., and Sai, D. V. R. (2013). Studies on Indigenous Microorganisms (IMOs) increasing Growth of Leaves Germination, Chlorophyll content and Differentiation between IMOs and Chemical Fertilizers in various crop plants. Int. J. Emerging Technologies in Computational and Applied Sciences, 4 (3): 313-318

[25] Hoitink, H. A. J., Madden, L. V., and Dorrance, E. A. (2006). Systematic resistance induced by Trichoderma spp: Interaction between the host the pathogen, the biocontrol agent and soil organic matter quality. Phytopathology 96(2) 186-189.

[26] Debelle, T., Friessen, D. K. (2001). Effect of enriching farm yard manure with mineral fertilizer on grain yield of maize at Bako, Western Ethiopia. Seventh Eastern and Southern Maize Conference 11-15 February. 335-337.

[27] Prell, J. (2010). Natural farming with indigenous microorganism. The Voice of Eco Agriculture. ACRES USA 40(1): $36-37$.

[28] Koon-Hui, W., Mike, D., Kim, C. (2013). Use of Korean Natural Farming for Vegetable Crop Production in Hawai'i $7 \mathrm{pp}$.

[29] Zende, G. K. (1996). Sugar Industry by Product and Crop Residues in Increasing Soil Fertility and Crop Productivity in Sugar Cane Agro Industrial Alternations, 351-369.

[30] Grisso, R., Mark, A., Wysor, W. G., David, H., and Wade, T. (2009). Precision Farming Tools: Soil Electrical Conductivity. Virginia Cooperative Extension, Virginia Tech publication. 442-508.

[31] Sparling, G. P., Schipper, L. A., Russel, J. M. (2001). Changes in soil properties after application of dairy factory effluent to New Zealand volcanic ash and pumice soils. Aust. J. Soil. Res., 39, 505-518.

[32] Narasimba, G., Babu, G. V. A. K., and Reddy, B.R. (1999). Cellulolytic activity of fungal cultures isolated from soil contaminated with effluents of cotton ginning industry. J. Environ. Biol., 20: 235-239. 
[33] Zuraihah, I. I., Aini, Z., and Farida, M. (2012). Effects of IMO and EM application on soil nutrients microbial population and crop yield. J. Trop. Agric. and Fd. Sc. 40(2): 257-263.

[34] Green, N. P. O., and Stout (1997). Biological Science. Cambridge University Press ( $3^{\text {rd }}$ edition) 216-220.

[35] Jusoh, C., Mohd, L., Latifah, A. M., and Puziah, A. L. (2013). Composting of rice straw with effective microorganisms (EM) and its influence on compost quality. Iranian Journal of Environmental Health Sciences \& Engineering 10: 17.
[36] Schumacher, B. A. (2002). Methods for the determination of total organic carbon (TOC) in soils and sediments. Ecological Risk Assessment Support Centre, Office of Research and Development US. Environmental Protection Agency. 1-23.

[37] Higa, T and Parr J (1994). Beneficial and Effective Microorganisms for a Sustainable Agriculture and Environment. Atami, Japan: International Nature Farming Research Center. 1-16. 